\title{
Effects of pyrolysis parameters on the yield and properties of biochar from pelletized sunflower husk
}

\author{
Katarzyna Wystalska ${ }^{1}$, Krystyna Malińska ${ }^{1,{ }^{*}}$, Renata Włodarczyk $^{2}$, and Olga Chajczyk $^{1}$ \\ ${ }^{1}$ Institute of Environmental Engineering, Częstochowa University of Technology, Brzeźnicka 60a, \\ 42-201 Częstochowa, Poland \\ ${ }^{2}$ Department of Energy Engineering, Częstochowa University of Technology, Brzeźnicka 60a, \\ 42-201 Częstochowa, Poland
}

\begin{abstract}
Pyrolysis of biomass residues from agriculture and food processing industry allows production of biochars with diverse physical and chemical properties for a wide range of applications in agriculture and environmental protection. Biochars produced from pelletized sunflower husks through slow pyrolysis in the range of temperatures $\left(480-580^{\circ} \mathrm{C}\right)$ showed total carbon of $70.53 \%-81.96 \%$, total nitrogen of $1.2 \%$, alkaline $\mathrm{pH}(9.37-10.32)$, low surface area $\left(0.93-2.91 \mathrm{~m}^{2} \mathrm{~g}^{-1}\right)$ and porosity of $13.23-15.43 \%$. Higher pyrolysis temperatures resulted in lower biochar yields. With the increase in temperature the content of organic matter, nitrogen, $\mathrm{Ca}$ and $\mathrm{Mg}$ decreased whereas the increase in temperature resulted in higher contents of total carbon and phosphorus. Produced biochars showed potential for agricultural applications.
\end{abstract}

\section{Introduction}

Thermal conversion of biomass through pyrolysis allows production of materials that can be used for a wide range of applications that provide solutions to the most pressing environmental problems [1-9]. However, the properties of biochars will determine the type of application and the efficiency of the processes involved. The literature provides a great number of studies on different types of biochars used as sorbents for removal of various organic and inorganic contaminants, soil amendments and fertilizers, supplementary materials for composting and anaerobic digestion, additives for remediation of contaminated soil, etc. [10-14]. The most recent applications include using biochar as a potential hydroponic growth substrate [15], a biochar composite membrane or a wood polymer composite $[16,17]$, a green roof substrate [18] or a microbial carrier [19]. The most important properties of biochars include chemical composition, porosity and surface area, $\mathrm{pH}$, and also surface functional groups. These properties can be "designed" by modifying the process of pyrolysis through temperature, heating and retention times

\footnotetext{
${ }^{*}$ Corresponding author: kmalinska@,is.pcz.czest.p1
} 
[20-22] and also by modifying the properties of substrates for biochar production (physically or chemically). Depending on the properties of biochar substrates, the increase in pyrolysis temperature can result in the increase in surface area [23] and carbon content [24] in the obtained biochars. Biochar can be produced from a wide range of substrates including agricultural residues such as sunflower husk [25]. However, the literature provides only few studies on converting pelletized sunflower husk into biochar and the effects of different pyrolysis parameters on the selected properties of the produced biochars.

The overall goal of this study was to analyse the effects of pyrolysis parameters (i.e. temperature, heating and retention times) on the yield and selected properties of biochars produced from pelletized sunflower husk.

\section{Materials and methods}

\subsection{Pelletized sunflower husk}

Pelletized sunflower husk (PSH) was used to produce biochar. The shape of the investigated pellets was typical for biomass pellets [26, 27], i.e. cylindrical elongated and regular with the diameter of $8 \mathrm{~mm}$ and the length from 5 to $25 \mathrm{~mm}$. The moisture (MC) and organic matter (OM) content of PSH was of $7.44 \%$ and $89.33 \%$ (d.b.), respectively. Selected properties of pelletized sunflower husk are presented in Table 1.

Table 1. Selected properties of pelletized sunflower husk (PSH).

\begin{tabular}{|c|c|c|c|c|c|}
\hline & DM, \% & OM, \% (d.b.) & pH & $\mathrm{C}_{\text {tot }}, \mathrm{g} \mathrm{kg}^{-1}$ & $\mathrm{~N}, \mathrm{~g} \mathrm{~kg}^{-1}$ \\
\hline PSH & 92.56 & 89.33 & 5.70 & 474.65 & 7.94 \\
\hline
\end{tabular}

\subsection{Pyrolysis parameters}

Pelletized sunflower husk was pyrolysed in a continuous pyrolysis reactor (PRW$\mathrm{S} 100 \times 780 / 11$, max. temperature up to $1100^{\circ} \mathrm{C}$, under nitrogen atmosphere of $5 \mathrm{dm}^{3} \mathrm{~m}^{-1}$ ) under different conditions of temperature, heating and retention times (Table 2). The real temperature inside of the reactor was measured by a thermocouple.

Table 2. Pyrolysis parameters (temperature, heating time, retention time) used in this study.

\begin{tabular}{|c|c|c|c|c|c|c|c|c|c|c|c|c|}
\hline Parameters & \multicolumn{12}{|c|}{ Values } \\
\hline Temperature,${ }^{\circ} \mathrm{C}$ & \multicolumn{4}{|c|}{480} & \multicolumn{4}{|c|}{530} & \multicolumn{4}{|c|}{580} \\
\hline $\begin{array}{l}\text { Heating time, } \\
\text { min }\end{array}$ & \multicolumn{2}{|c|}{65} & \multicolumn{2}{|c|}{120} & \multicolumn{2}{|c|}{65} & \multicolumn{2}{|c|}{120} & \multicolumn{2}{|c|}{65} & \multicolumn{2}{|c|}{120} \\
\hline $\begin{array}{l}\text { Retention time, } \\
\text { min }\end{array}$ & 10 & 60 & 10 & 60 & 10 & 60 & 10 & 60 & 10 & 60 & 10 & 60 \\
\hline
\end{tabular}

Pelletized sunflower husk ( $100 \mathrm{~g})$ was placed in the reactor and heated with the temperature of $480^{\circ} \mathrm{C}, 530^{\circ} \mathrm{C}$ and $580^{\circ} \mathrm{C}$ (assumed values) at different heating times $(65$ and 120 minutes) and retention times (10 and 60 minutes). After the completion of the process the samples were left in the reactor until they reached room temperature. The temperatures measured by a thermocouple during pyrolysis were lower than the values assumed at the beginning of the process (Table 3 ). 
Table 3. Temperatures during pyrolysis measured by a thermocouple.

\begin{tabular}{|c|c|c|c|c|c|c|c|c|c|c|c|c|}
\hline $\begin{array}{c}\text { Pyrolysis } \\
\text { parameters } \\
\text { temperature, }\end{array}$ & 480 & 530 & 580 & 480 & 530 & 580 & 480 & 530 & 580 & 480 & 530 & 580 \\
$\begin{array}{c}\text { heating time, } \\
\text { retention time) }\end{array}$ & 10 & 10 & 10 & 10 & 10 & 10 & 60 & 60 & 60 & 60 & 60 & 60 \\
\hline $\begin{array}{c}\text { Temperatures } \\
\text { measured during } \\
\text { the process, }{ }^{\circ} \mathrm{C}\end{array}$ & 426 & 480 & 537 & 444 & 496 & 550 & 463 & 514 & 564 & 461 & 513 & 564 \\
\hline
\end{tabular}

\subsection{Physicochemical and physical analyses}

Biochars obtained from pyrolysis of pelletized sunflower husk were analysed for moisture content (by oven drying in $105^{\circ} \mathrm{C}$ ), organic matter (by incineration in a muffle furnace at $550^{\circ} \mathrm{C}$ for $5 \mathrm{~h}$ ), total carbon (by MultiN/C, Analytkjena, in 4 replications), $\mathrm{pH}(1: 10 \mathrm{v} / \mathrm{v}$, in 2 replications), Kjeldahl nitrogen, and selected elements (by ICP-OES Thermo Elemental IRIS INTREPID II XSP DUO, in 3 replications). Porosity and surface area were determined with the mercury intrusion porosimeter (PoroMaster 33). In addition, density and particle size of the produced biochars were analysed and biochar surface was analysed with scanning microscopy (SU3500 Hitachi).

\section{Results and discussion}

\subsection{Pyrolysis efficiency, moisture and organic matter contents}

The efficiency of pyrolysis, i.e. the yield of conversion of pelletized sunflower husk (Fig. 1) into biochar depended on temperature and retention time (Table 4).
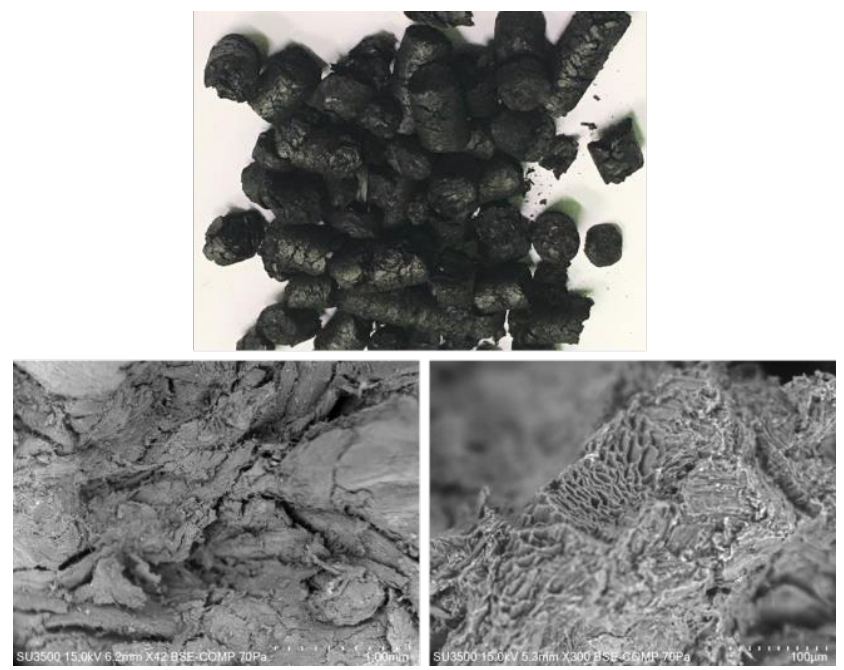

Fig 1. Biochar produced from pelletized sunflower husk (magnified by 42 and 300 times).

The biochar yield was in the range of $30.04-36.23 \%$ of the initial substrate weight and decreased with the increase in temperature at the same heating and retention times. This is in line with other studies that demonstrated that the biochar yield depends on pyrolysis 
temperature and retention time [28-31]. For example, biochar yield obtained from pyrolysis of pelletized sunflower at $400^{\circ} \mathrm{C}$ decreased from $36.17 \%$ to $33.19 \%$ at $500^{\circ} \mathrm{C}$ [27].

Table 4. Pyrolysis parameters (temperature, heating time, retention time) used in this study.

\begin{tabular}{|c|c|c|c|c|}
\hline Pyrolysis parameters & $\begin{array}{l}\text { Biochar } \\
\text { yield, \% (d.b. } \\
\text { of PSH) }\end{array}$ & $\begin{array}{l}\text { Average } \\
\text { yield, \% }\end{array}$ & $\begin{array}{c}\text { Moisture } \\
\text { content, \% }\end{array}$ & $\begin{array}{l}\text { Organic matter } \\
\text { content, } \%\end{array}$ \\
\hline $480 / 65 / 10$ & $35.63 \pm 0.24$ & \multirow{3}{*}{32.68} & $2.69 \pm 0.42$ & $88.21 \pm 0.73$ \\
\hline $530 / 65 / 10$ & $32.03 \pm 0.10$ & & $3.24 \pm 0.90$ & $87.23 \pm 1.09$ \\
\hline $580 / 65 / 10$ & $30.39 \pm 0.28$ & & $3.31 \pm 0.51$ & $86.19 \pm 0.88$ \\
\hline $480 / 120 / 10$ & $36.23 \pm 0.39$ & \multirow{3}{*}{33.74} & $2.30 \pm 0.87$ & $88.77 \pm 1.20$ \\
\hline $530 / 120 / 10$ & $33.46 \pm 0.36$ & & $2.81 \pm 0.99$ & $87.92 \pm 1.43$ \\
\hline $580 / 120 / 10$ & $31.54 \pm 0.22$ & & $2.53 \pm 0.72$ & $87.48 \pm 1.23$ \\
\hline $480 / 120 / 60$ & $33.91 \pm 0.13$ & \multirow{3}{*}{32.49} & $3.48 \pm 0.44$ & $86.60 \pm 0.87$ \\
\hline $530 / 120 / 60$ & $31.96 \pm 0.04$ & & $3.20 \pm 0.59$ & $86.54 \pm 0.52$ \\
\hline $580 / 120 / 60$ & $31.60 \pm 0.33$ & & $3.55 \pm 0.24$ & $85.87 \pm 0.56$ \\
\hline $480 / 65 / 60$ & $33.42 \pm 0.69$ & \multirow{3}{*}{31.59} & $2.94 \pm 0.54$ & $87.68 \pm 0.78$ \\
\hline $530 / 65 / 60$ & $31.31 \pm 0.62$ & & $3.61 \pm 0.47$ & $86.24 \pm 0.47$ \\
\hline $580 / 65 / 60$ & $30.04 \pm 0.04$ & & $3.18 \pm 0.22$ & $86.18 \pm 0.07$ \\
\hline
\end{tabular}

The retention time of 60 min resulted in slightly lower biochar yield when compared to time of $10 \mathrm{~min}$. Also, heating time had an effect on the biochar yield. Longer heating times (120 min) resulted in higher average biochar yield. The content of organic matter decreased with the increase in temperature which was reported in other studies [27].

\subsection{Total carbon, total nitrogen, selected elements and $\mathrm{pH}$}

The total carbon content of biochars produced at different pyrolysis parameters ranged from $70.53 \%$ to $81.96 \%$ (Table 5), as higher temperatures result in higher carbonization. Heating time of $65 \mathrm{~min}$ led to higher contents of total carbon at the retention time of $60 \mathrm{~min}$ (79.43\%) as compared to $10 \mathrm{~min}(75.29 \%)$. The heating time of $120 \mathrm{~min}$ and the retention time of 60 min resulted in higher carbon contents in biochars $(78.99 \%)$ than in biochars obtained at the same heating time but at the retention time of $10 \mathrm{~min}(78.71 \%)$.

Table 5. Total carbon, total nitrogen and $\mathrm{pH}$ of produced biochars.

\begin{tabular}{|c|c|c|c|c|}
\hline Pyrolysis parameters & $\mathrm{C}_{\text {tot }}, \%$ & $\begin{array}{c}\mathrm{C}_{\text {tot }} \\
\text { (average), \% }\end{array}$ & $\mathbf{N}_{\text {tot }}, \%$ & pH \\
\hline $480 / 65 / 10$ & $70.53 \pm 0.72$ & \multirow{3}{*}{75.29} & $1.25 \pm 0.02$ & $9.89 \pm 0.03$ \\
\hline $530 / 65 / 10$ & $75.27 \pm 0.37$ & & $1.22 \pm 0.05$ & $10.09 \pm 0.03$ \\
\hline $580 / 65 / 10$ & $80.06 \pm 1.23$ & & $1.21 \pm 0.06$ & $9.57 \pm 0.03$ \\
\hline $480 / 120 / 10$ & $77.35 \pm 0.97$ & \multirow{3}{*}{78.71} & $1.29 \pm 0.04$ & $9.90 \pm 0.14$ \\
\hline $530 / 120 / 10$ & $79.02 \pm 0.61$ & & $1.28 \pm 0.04$ & $9.91 \pm 0.07$ \\
\hline $580 / 120 / 10$ & $79.74 \pm 0.89$ & & $1.22 \pm 0.04$ & $9.53 \pm 0.03$ \\
\hline $480 / 120 / 60$ & $77.28 \pm 0.54$ & \multirow{3}{*}{78.99} & $1.42 \pm 0.06$ & $10.03 \pm 0.03$ \\
\hline $530 / 120 / 60$ & $79.53 \pm 0.99$ & & $1.27 \pm 0.03$ & $9.53 \pm 0.03$ \\
\hline $580 / 120 / 60$ & $80.18 \pm 0.98$ & & $1.22 \pm 0.06$ & $9.37 \pm 0.03$ \\
\hline $480 / 65 / 60$ & $77.63 \pm 0.32$ & \multirow{3}{*}{79.43} & $1.27 \pm 0.03$ & $10.32 \pm 0.07$ \\
\hline $530 / 65 / 60$ & $78.70 \pm 0.69$ & & $1.24 \pm 0.07$ & $9.83 \pm 0.07$ \\
\hline $580 / 65 / 60$ & $81.96 \pm 0.42$ & & $1.17 \pm 0.05$ & $9.47 \pm 0.07$ \\
\hline
\end{tabular}

The content of nitrogen decreased with the increase in temperature due to conversion of nitrogen compounds into gaseous substances. The heating and retention times did not have 
an effect of the nitrogen content. The content of total carbon and nitrogen depends on the properties of biochar substrates. For example, biochars obtained from sewage sludge and cattle manure showed the carbon content of $20 \%$ and $42 \%\left(525^{\circ} \mathrm{C}\right)$ and nitrogen content of $0.94 \%$ and $1.8 \%$, respectively [32]. The $\mathrm{pH}$ values of the obtained biochars ranged from 9.37-10.32. The alkaline character was mostly due to the presence of $\mathrm{Ca}^{2+}, \mathrm{Mg}^{2+}, \mathrm{Na}$, $\mathrm{K}$ (Table 6). No significant differences in $\mathrm{pH}$ values with the increase in temperature were observed. However, significant differences in $\mathrm{pH}$ values were observed in biochars pyrolysed at $300^{\circ} \mathrm{C}\left(\mathrm{pH} \mathrm{9.5)}\right.$ and at $600^{\circ} \mathrm{C}(\mathrm{pH} 11.5)$ [33]. The analysis of water biochar extracts showed increased concentration of phosphorous with the increased temperatures (Table 6). The phosphorous concentrations were very low which could result from transformation of phosphorous into less water soluble forms during pyrolysis. Similar results were obtained by other researchers [33]. The concentration of $\mathrm{Ca}$ and $\mathrm{Mg}$ decreased with the increase in temperature. Higher pyrolysis temperatures could result in lower water solubility of these forms.

Table 6. The content of selected elements in water extracts from produced biochars.

\begin{tabular}{|c|c|c|c|c|c|c|c|}
\hline $\begin{array}{l}\text { Pyrolysis } \\
\text { parameters }\end{array}$ & $\mathrm{Ca}, \mathrm{g} \mathrm{kg}^{-1}$ & $\begin{array}{c}\mathrm{Mg}, \\
\mathrm{g} \mathrm{kg}^{-1}\end{array}$ & $\begin{array}{c}\mathrm{Na}, \\
\mathrm{g} \mathrm{kg}^{-1}\end{array}$ & $\begin{array}{c}\mathbf{P}, \\
\mathrm{g} \mathrm{kg}^{-1}\end{array}$ & $\begin{array}{c}\mathrm{K} \\
\mathrm{g} \mathrm{kg}^{-1}\end{array}$ & $\begin{array}{c}\text { B, } \\
\mathrm{g} \mathrm{kg}^{-1}\end{array}$ & $\begin{array}{c}\mathrm{Fe}, \\
\mathrm{g} \mathrm{kg}^{-1}\end{array}$ \\
\hline $480 / 65 / 10$ & 0.522 & 0.472 & 0.015 & 0.006 & 0 & 0.016 & 0.006 \\
\hline $530 / 65 / 10$ & 0.243 & 0.441 & 0.012 & 0.004 & 0 & 0.021 & 0.003 \\
\hline $580 / 65 / 10$ & 0.331 & 0.189 & 0.012 & 0.045 & 0 & 0.020 & 0.003 \\
\hline $480 / 120 / 10$ & 0.773 & 0.617 & 0.012 & 0.004 & 0 & 0.015 & 0.002 \\
\hline $530 / 120 / 10$ & 0.298 & 0.322 & 0.013 & 0.004 & 0 & 0.019 & 0.004 \\
\hline $580 / 120 / 10$ & 0.233 & 0.150 & 0.012 & 0.086 & 0 & 0.017 & 0.002 \\
\hline $480 / 120 / 60$ & 0.513 & 0.382 & 0.013 & 0.006 & 0 & 0.020 & 0.002 \\
\hline $530 / 120 / 60$ & 0.355 & 0.185 & 0.009 & 0.026 & 0 & 0.019 & 0.003 \\
\hline $580 / 120 / 60$ & 0.202 & 0.143 & 0.014 & 0.120 & 0 & 0.015 & 0.001 \\
\hline $480 / 65 / 60$ & 0.376 & 0.384 & 0.014 & 0.003 & 0 & 0.017 & 0.001 \\
\hline $530 / 65 / 60$ & 0.301 & 0.191 & 0.008 & 0.018 & 0 & 0.016 & 0.001 \\
\hline $580 / 65 / 60$ & 0.218 & 0.118 & 0.012 & 0.082 & 0 & 0.010 & 0.003 \\
\hline
\end{tabular}

\subsection{Surface area and porosity}

The surface area of the obtained biochars was low and ranged from 0.93 to $2.91 \mathrm{~m}^{2} \mathrm{~g}^{-1}$ and was not affected by temperature (Table 7). Surface area of biochars depends on the properties of substrates, including mechanical pretreatment of substrates (such as pelletizing). Similar results were reported in other studies [28]. It was observed that biochars with low surface area showed potentials towards application as sorbents for nonferrous metals [28]. Porosity of the obtained biochars ranged from 13.23-15.43\%. The results showed that the retention and heating times can affect biochar porosity. The particle size of the investigated biochars ranged from $0.29-1.99 \mathrm{~mm}$. Higher temperature and shorter heating and retention time (up to $105-500^{\circ} \mathrm{C} \mathrm{s}^{-1}$ ) resulted in finer particles of biochar $(50-2000 \mu \mathrm{m})$ [20]. Slower pyrolysis results in coarser particles of biochars [21]. 
Table 7. Porosity, surface area and density of produced biochars.

\begin{tabular}{|c|c|c|c|}
\hline $\begin{array}{c}\text { Pyrolysis } \\
\text { parameters }\end{array}$ & Open porosity, $\%$ & Surface area, $\mathbf{~ m}^{\mathbf{2}} \mathbf{g}^{\mathbf{- 1}}$ & Density, $\mathbf{g ~ c m}^{\mathbf{- 3}}$ \\
\hline $480 / 65 / 10$ & 13.56 & 1.32 & 1.67 \\
\hline $480 / 65 / 60$ & 13.23 & 1.22 & 1.22 \\
\hline $480 / 120 / 10$ & 14.43 & 1.64 & 0.92 \\
\hline $480 / 120 / 60$ & 15.43 & 1.76 & 0.76 \\
\hline
\end{tabular}

\section{Conclusions}

Pyrolysis parameters, i.e. temperature, heating and retention times determined the biochar yield and properties. Higher temperatures resulted in lower biochar yield whereas longer heating times resulted in higher biochar yield. Higher retention times caused decrease in the biochar yield. With the increase in temperature organic matter, nitrogen, $\mathrm{Ca}$ and $\mathrm{Mg}$ in biochars decreased whereas the total carbon and phosphorus increased. Produced biochars were of alkaline. Low surface area of the obtained biochars does not limit their application as sorbents (e.g. for nonferrous metals). The produced biochars were the source of calcium, iron, boron, magnesium and phosphorus - these elements are crucial for plant growth. The investigated biochars demonstrated required properties for application in agriculture or protection of the environment.

This study was supported by the statutory grant No. BS/PB-401-301/11 at Częstochowa University of Technology (Poland).

\section{References}

1. A. Szymonik, J. Lach., K. Malińska, Ecol. Chem. Eng. S. 24, 1, 65-85 (2017)

2. A. Colantoni, N. Evic, R. Lord, S. Retschitzegger, A.R. Proto, F. Gallucci, D. Monarca, Renew. Sust. Energ. Rev. 64, 187-194 (2016)

3. B. Jabłońska, A. Kityk, M. Busch, P. Huber, J. Environ. Manage. 190, 80-90 (2017)

4. W. Czekała, J. Dach. R. Dong, D. Janczak, K. Malińska, K. Jóźwiakowski, A. Smurzyńska, M. Cieślik, Biosyst. Eng. 160, 25-29 (2017)

5. D. Kufka, M. Bucha, Górnictwo Odkrywkowe 57, 1, 5-10 (2017)

6. A. Sorgonà, L. Longo, A.R. Proto, P. Cavalletti, M. Cecchini, L. Salvati, F. Gallucci, A. Colantoni, Procedia Soc. Behav. Sci. 223, 871-878 (2016)

7. M. Kałużyński, S. Jabłoński, J. Kaczmarczyk, Ł. Świątek K. Pstrowka, M. Łukaszewicz, J. Energy Inst. (in press) (2017)

8. J. Lehmann, Front. Ecol. Environ. 5, 7, 381-387 (2007)

9. Z. Bis, Czysta Energia 3, 38-42 (2015)

10. H.P. Schmidt, Ithaka Journal 1, 286-289 (2012)

11. Y.M. Awad, S-E. Leec, M.B.M. Ahmenda, N.T. Vud, M. Farooqe, I.S. Kimd, H.S. Kimf, M. Vithanageg, A.R.A. Usmanh, M. Al-Wabelh, E. Meersi, E.E. Kwonj, Y.S Oka, J. Clean Prod. (in press) (2017)

12. A. Ghattar, X. Zhu, B. Chen, Environ. Pollut. (in press) (2017)

13. D.D. Douds Jr., J. Lee, J. Uknalis, A.A. Boateng, C. Ziegler-Ulsh, Compost Sci. Util. 22, 253-262 (2014)

14. O. Das, A.K. Sarmah, D. Bhattacharyya, Sci. Total Environ. 512-513, 326-336 (2015) 
15. C.T.N. Cao, C. Farrell, P.E. Kristiansen, J.P. Rayner, Ecol. Eng. 71, 368-374 (2014)

16. W. Czekała, K. Malińska, R. Cáceres, D. Janczak, J. Dach, A. Lewicki, Bioresour. Technol. 200, 921-927 (2016)

17. D. Janczak, K. Malińska, W. Czekała, R. Cáceres, A. Lewicki, J. Dach, Waste Manage. 66, 36-45 (2017)

18. K. Malińska, M. Golańska, R. Cáceres, A. Rorat, P. Weisser, E. Ślęzak, Bioresour. Technol. 225, 206-214 (2017)

19. A. Latawiec, L. Peake, H. Baxter, G. Cornelissen, K. Grotkiewicz, S. Hale, J.B. Królczyk, M. Kubon, A. Łopatka, A. Medyńska-Juraszek, B.J. Reid, G. Siebielec, S.P. Sohi, Z. Spiak, B.B.N. Strassburg, J. Environ. Eng. Landsc. 25, 2, 208-222 (2017)

20. J. Królczyk, A. Latawiec, M. Kuboń, Pol. J. Eviron. Stud. 23, 3, 663-672 (2014)

21. M. Kacprzak, E. Neczaj, K. Fijałkowski, A. Grobelak, A. Grosser, M. Worwąg, A. Rorat, H. Brattebo, Å. Almås, B.R. Singh, Environ. Res. 156, 39-46 (2017)

22. K. Jindo, H. Mizumoto, Y. Sawada, M.A. Sanchez-Monedero, T. Sonoki, Biogeosciences 11, 6613-6621 (2014)

23. M. Chen, P. Xu, G. Zeng, C. Yang, D. Huang, J. Zhang, Biotechnol. Adv. 33, 745-755 (2015)

24. S. Głuszek, L. Sas-Paszt, B. Sumorok, R. Kozera, Pol. J. Microbiol. 66, 2, 151-161 (2017)

25. E. Cetin, B. Moghtaderi, R. Gupta, T.F. Wall, Fuel 83, 2139-2150 (2004)

26. A. Downie, A. Crosky, P. Munroe, Physical properties of biochar, In: J. Lehmann, S. Joseph Biochar for Environmental Management - Science and Technology, (Earthscans, London, 2009)

27. P. Giudicianni, S. Pindozzi, C.M. Grottola, F. Stanzione, S. Faugno, M. Fagnano, N. Fiorentino, R. Ragucci, Waste Manage. 61, 288-299 (2017)

28. J. Tang, W. Zhu, R. Kookana, A. Katayama, J. Biosci. Bioeng. 116, 6, 653-659 (2017)

29. M. Ahmad, A.U. Rajapaksha, J.E. Lim, M. Zhang, D.M. Bolan, M. Vithanage, S.S. Lee, S.Y. Ok, Chemosphere 99, 19-33 (2014)

30. R. Brown, Biochar production technology. In: Lehmann J., Joseph S., Biochar for Environmental Management Science and Technology - Science and Technology, (Earthscans, London, 2009)

31. P. De Wild, H. Reith, H. J. Heeres, Biofules 2, 2, 185-208 (2011)

32. N. Ruiz-Gomez, V. Quispe, J. Abrego, M. Atienza-Marinez, M.B. Murillo, G. Gea, Waste Manage. 59, 211-221 (2017)

33. W. Song, M. Guo, J. Anal. Appl. Pyrolysis 94, 138-145 (2012) 